\title{
ESSENTIAL OILS CHEMICAL VARIABILITY OF SEVEN POPULATIONS OF SALVIA OFFICINALIS L. IN NORTH OF ALBANIA
}

\author{
Alban Ibraliu' ${ }^{1}$ Adrian Doko ${ }^{2}$, Avni Hajdari ${ }^{3}$, Nazim Gruda ${ }^{4}$, Zlatko Šatović ${ }^{5,6}$, \\ Ivana Cvetkovikj Karanfilova ${ }^{7^{*}}$, Gjoshe Stefkov ${ }^{8}$ \\ ${ }^{1}$ Department of Agronomy Sciences, Faculty of Agriculture and Environment, \\ Agricultural University of Tirana, Kodër Kamëz Tirana, Albania \\ ${ }^{2}$ Department of Ecology and Agro-Environment, Faculty of Agriculture and Environment, \\ Agricultural University of Tirana, Kodër Kamëz Tirana, Albania \\ ${ }^{3}$ Department of Biology, Faculty of Mathematical and Natural Science, \\ University of Prishtina "Hasan Prishtina", Mother Theresa St., 10000 Prishtinë, Kosovo \\ ${ }^{4}$ Department of Horticultural Sciences, University of Bonn, Bonn, Germany \\ ${ }^{5}$ University of Zagreb, Faculty of Agriculture, Department of Seed Science and Technology, \\ Svetošimunska cesta 25, 10000 Zagreb, Croatia \\ ${ }^{6}$ Centre of Excellence for Biodiversity and Molecular Plant Breeding (CroP-BioDiv), \\ Svetošimunska cesta 25, 10000 Zagreb, Croatia \\ $7^{7 *}$ Centre for Natural Products, Faculty of Pharmacy, Ss. Cyril and Methodius University, Majka Tereza 47, \\ 1000 Skopje, North Macedonia \\ ${ }^{8}$ Institute of Pharmacognosy, Faculty of Pharmacy, Ss. Cyril and Methodius University, \\ Majka Tereza 47, 1000 Skopje, North Macedonia \\ ivanacvetkovikj@ff.ukim.edu.mk, ivanacvetkovikj@gmail.com
}

Essential oils from seven populations of Dalmatian sage from the North of Albania were extracted and analyzed according European Pharmacopeia 7.0. The yield differed from 1.95 to $2.75 \%$ v/w. The GCFID-MS analysis of the sage oil revealed 42 constituents. Camphor (20.50-29.74 \%), followed by $\alpha$-thujone (19.87-24.29\%), 1,8-cineole (6.88-12.64\%) and $\beta$-thujone (4.00-9.14\%) were predominant constituents in all analyzed populations, representing 55.70-68.00\% of the total components. All of the analyzed sage populations from northern Albania comply with ISO 6571/2008 standard and European Pharmacopeia 7.0. for Dalmatian sage essential oil content, while only four populations met the requirements of the ISO 9909/1997 standard for Dalmatian sage essential oil's composition.

Keywords: sage populations; essential oil; chemotype; medicinal and aromatic plants; North of Albania

\section{ХЕМИСКА ВАРИЈАБИЛНОСТ НА ЕТЕРИЧНИ МАСЛА ОД СЕДУМ ПОПУЛАЦИИ НА SALVIA OFFICINALIS L. ОД СЕВЕРНА АЛБАНИЈА}

Етерични масла од седум далматински популации на жалфија од северот на Албанија беа изолирани и анализирани според Европската фармакопеја 7.0. Приносот варираше од 1,95 до 2,75 \%. Жалфиите беа анализирани со GS-FID-MS, по што беа идентификувани 42 конституенти. Камфор (20,50-29,74 \%), проследен со $\alpha$-тујон (19,87-24,29 \%), 1,8-цинеол (6,88-12,64 \%) и $\beta$-тујон $(4,00-9,14 \%)$ беа доминантни конституенти во сите испитувани популации, претставувајќи 55,7068,00 \% од вкупните компоненти. Сите анализирани популации на жалфија од северна Албанија се во согласност со ISO 6571/2008 и со Европската фармакопеја 7.0 за содржината на етеричното масло во далматинската жалфија, додека само четири популации го исполнија барањето на ISO 9909/1997 што се однесува на хемискиот состав на етеричното масло на далматинската жалфија. 
Клучни зборови: популации на жалфија; етерично масло; хемотип; лековити и ароматични растенија; северна Албанија

\section{INTRODUCTION}

Nowadays, Salvia officinalis L. (Lamiaceae), also known as Dalmatian sage, is a flavorful and much used medicinal plant throughout the world. It is a perennial evergreen subshrub, native to the Mediterranean region, up to $0.5-1.0 \mathrm{~m}$ high with woody stems and greyish leaves $[1,2]$. Common sage has been used for a long time as traditional herbal medicine against a variety of diseases, for culinary purposes, and as a condiment [1-8].

Based on its great economic and industrial value, $S$. officinalis $\mathrm{L}$. is the most important medicinal and aromatic plant in Albania. Additionally, Albania is an important exporter of medicinal and aromatic plants in Europe and the most important exporter of sage to the USA [9-11]. In Albania, S. officinalis L., is one of the most frequently used herbs in folk medicine. It is used for different medicinal purposes like sore throats, tonsillitis, a cough, the flu, "good for the health", "to strengthen the stomach", digestion, etc. [12]. However, over the past 20 years, the wild populations of sage have declined so drastically that now it is classified in the Red Book of Albania as "vulnerable"- VU A1b [13].

Sage extracts and essential oils are phytotherapeutically useful. S. officinalis L. essential oil has a wide range of biological activities, and it is used in the treatment of many diseases because of its viricidal, cytotoxic, antimutagenic, antioxidant, antimicrobial, hypoglycaemic, anti-inflammatory, fungistatic, astringent, eupeptic and anti-hydrotic effects. Additionally, this plant is used as digestive stimulator, appetizer and performance enhancer [14-16].

A substantial part of the phyto-therapeutical effects are determined by the extract and essential oil content, its composition, and other substances. Many medicinally valuable metabolites including monoterpenes (e.g., $\alpha$ - and $\beta$-thujone, 1,8-cineole, and camphor), diterpenes (e.g., carnosic acid), triterpenes (oleanolic and ursolic acids) and phenolic compounds like rosmarinic acid are identified in the distilled oil or in polar extracts from sage leaves $[1,17,18]$.

Essential oils of more than 32 populations of S. officinalis from 11 Balkan countries (24 indigenous populations and eight non-indigenous, cultivated or naturalized, populations) including six wild growing populations from Albania were analyzed by Cvetkovikj et al. [19]. Schmiderer et al. [20] investigated the differences between the sage populations in the South and North of Albania. All of these studied populations are not the subject of the present work.

The yield of Dalmatian sage essential oil is regulated by the European Pharmacopoeia 7.0 [21] and the International Organization for Standardization (ISO 6571/2008) [22]. According to these regulations, the minimum yield must be $15.00 \mathrm{ml} / \mathrm{kg}$ or $1.50 \% \mathrm{~V} / \mathrm{m}$ of essential oil for the whole dried leaf. On the other hand, the chemical composition is regulated within the ISO 9909/1997 standard, which fixes content requirements for 11 constituents, i.e., $\alpha$-pinene 1.00-6.50\%, camphene $1.50-7.00 \%$, limonene $0.50-3.00 \%, 1,8$-cineole $5.50-13.00 \%$, linalool + linalyl acetate $\leq 1.00 \%, \alpha$-thujone 18.00 $43.00 \%, \beta$-thujone $3.00-8.50 \%$, camphor 4.50 $24.50 \%$, bornyl acetate $\leq 2.50 \%$, and $\alpha$-humulene $\leq 12.00 \%$ [23].

Previous reports published on the essential oil composition of sage in Albania and South-EasternEuropean countries showed a variation in the content and chemical composition. Therefore, a number of classifications have been proposed $[1,4,5,18$ 20]. The most commonly reported major constituents of Dalmatian sage essential oil have been $\alpha$ thujone, $\beta$-thujone, camphor, and 1,8-cineole.

The aim of this study was to assess the yield and chemical composition of the essential oil of seven wild sage populations from the North of Albania and its compliance to ISO standards.

\section{EXPERIMENTAL SECTION}

\subsection{Plant material}

210 samples of Salvia officinalis L. were collected at the full blooming time in the beginning of July 2012 in the North of Albania (Malësia e Madhe and Shkodra in District of Shkodra) from seven localities (30 different individual samples from each population) (Table 1).

The leaves were air dried, packed in paper bags and kept in a dark and cold place until analysis. Voucher specimens were deposited at the Crop Production Department, Agricultural University of Tirana (Table 1). Plant identity was verified by A. Ibraliu according to Albanian Flora [24]. 
Table 1

Characterization of the collection sites of the S. officinalis L., collected in the North of Albania

\begin{tabular}{|c|c|c|c|c|c|c|c|}
\hline Population & $\begin{array}{r}\text { Voucher } \\
\text { specimen }\end{array}$ & Collection sites & $\begin{array}{l}\mathrm{Ht} \\
(\mathrm{m})\end{array}$ & $\mathrm{N}$ & $\mathrm{E}$ & Exposition & $\begin{array}{l}\text { Sample } \\
\text { No. }\end{array}$ \\
\hline P1 & $\mathrm{Al} 025$ & $\begin{array}{l}\text { Mali i Taraboshit, } \\
\text { Shkodër }\end{array}$ & 89 & $42^{\circ} 04^{\prime} 36^{\prime \prime}$ & $19^{\circ} 26^{\prime} 65^{\prime \prime}$ & $\begin{array}{l}\text { W - The North- } \\
\text { ern Field }\end{array}$ & 30 \\
\hline $\mathrm{P} 2$ & AI 026 & $\begin{array}{l}\text { Mali i Rrencit, } \\
\text { Malësia e Madhe }\end{array}$ & 81 & $41^{\circ} 55^{\prime} 44^{\prime \prime}$ & $19^{\circ} 26^{\prime} 74^{\prime \prime}$ & $\begin{array}{l}\text { NE - Northern } \\
\text { Hilly }\end{array}$ & 30 \\
\hline P3 & AI 027 & $\begin{array}{l}\text { Brigje-Hani i Hotit, } \\
\text { Malësia e Madhe }\end{array}$ & 406 & $42^{\circ} 20^{\prime} 57^{\prime \prime}$ & $19^{\circ} 27^{\prime} 29^{\prime \prime}$ & $\begin{array}{l}\text { SE - The Central } \\
\text { Hilly }\end{array}$ & 30 \\
\hline P4 & AI 028 & $\begin{array}{l}\text { Zagore, } \\
\text { Malësia e Madhe }\end{array}$ & 478 & $42^{\circ} 17^{\prime} 57^{\prime \prime}$ & $19^{\circ} 30^{\prime} 47^{\prime \prime}$ & $\begin{array}{l}\mathrm{NE} \text { - Northern } \\
\text { Maintains }\end{array}$ & 30 \\
\hline P5 & AI 029 & $\begin{array}{l}\text { Rec, } \\
\text { Malësia e Madhe }\end{array}$ & 396 & $42^{\circ} 13^{\prime} 33^{\prime \prime}$ & $19^{\circ} 29^{\prime} 57^{\prime \prime}$ & $\begin{array}{l}\mathrm{NE} \text { - The Central } \\
\text { Hilly }\end{array}$ & 30 \\
\hline P6 & AI 030 & $\begin{array}{l}\text { Vorf, } \\
\text { Malësia e Madhe }\end{array}$ & 187 & $42^{\circ} 09^{\prime} 3.44^{\prime \prime}$ & $19^{\circ} 39^{\prime} 47^{\prime \prime}$ & $\begin{array}{l}\text { SE - South-west- } \\
\text { ern Hilly }\end{array}$ & 30 \\
\hline P7 & AI 031 & Leqet e Hotit & 250 & $42^{\circ} 41^{\prime} 01^{\prime \prime}$ & $19^{\circ} 50^{\prime} 36^{\prime \prime}$ & & 30 \\
\hline
\end{tabular}

\subsection{Essential oil isolation}

Essential oil isolation from dried sage leaves, as an average sample of the 30 different individual samples of every population, was performed by hydrodistillation in an all-glass Clevenger apparatus for two hours, following the procedure of the European Pharmacopeia (2.8.12) [21]. These samples were stored at $-18{ }^{\circ} \mathrm{C}$ in the freezer until further analysis.

\subsection{Analysis of essential oils' chemical composition}

Each of the seven different essential oils was dissolved in xylene (10:990, v/v) for GC analyses. Oil samples were analyzed on a gas chromatography system (Agilent 7890A) equipped with FID detector and mass spectrometer detector (Agilent 5975C), using HP-5ms capillary column (30 m $\times$ $0.25 \mathrm{~mm}$, film thickness $0.25 \mu \mathrm{m}$ ).

Analytical conditions were as follows: oven temperature was set at $60{ }^{\circ} \mathrm{C}$ for $0 \mathrm{~min}$, then increased by $3{ }^{\circ} \mathrm{C} / \mathrm{min}$ to $240{ }^{\circ} \mathrm{C}$ and held there for 1 min and then it was increased to $280{ }^{\circ} \mathrm{C}$ at a rate of $10{ }^{\circ} \mathrm{C} / \mathrm{min}$ where was held for $1 \mathrm{~min}$; helium was used as the carrier gas at a flow rate of $1 \mathrm{ml} / \mathrm{min}$; temperature of the injector was $220^{\circ} \mathrm{C}$ and that of the FID detector was $270{ }^{\circ} \mathrm{C}$; the GC split was ratio $1: 1$. The injection volume was $1.0 \mu \mathrm{l}$.

The mass spectrometry conditions were as follows: ionization voltage $70 \mathrm{eV}$, ion source temperature $230{ }^{\circ} \mathrm{C}$, transfer line temperature $280{ }^{\circ} \mathrm{C}$, and mass range from 50-550 Da. The MS was operated in scan mode.

\subsection{Identification of the components}

The compounds were identified by comparing their Kovats (retention) indices with those in the literature [25]. The Kovats (retention) indices were determined using a mixture of a homologous series of normal alkanes $\left(\mathrm{C}_{9}-\mathrm{C}_{25}\right)$ analyzed under the $\mathrm{Au}$ tomated Mass Spectral Deconvolution and Identification System (AMDIS) conditions [26]. Confirmation was done by comparing the mass spectra obtained from AMDIS with the reference spectra from NIST (National Institute of Standards and Technology), Wiley and Adams mass spectra libraries. Quantification of the essential oils components was performed using the normalization method of the GC/FID peak areas.

\subsection{Statistical analysis}

Correlations among seven main essential oil constituents were calculated by PROC Corr in SAS [27]. The Principal Component Analysis (PCA) based on the main constituents was performed using PROC PRINCOMP in SAS. Pairwise Euclidean distances among seven populations were calculated and used in unweighted pair-group average (UPGMA) cluster analysis. Support for clades was evaluated by nonparametric bootstrapping [28] with 10.000 replicates in PAST ver. 2.01 [29].

\section{RESULTS AND DISCUSSION}

The yield of essential oil differed between sage populations and ranged from 1.95 to $2.75 \%$ 
(Table 2). The highest yield was determined in P2 $(2.75 \%)$, while the lowest yield of essential oils was observed in P5 (1.95\%). All populations met the requirements of the European Pharmacopeia 7.0 and ISO 6571/2008 standard for Dalmatian sage essential oil content $[21,22]$. In all of the essential oils analyzed, 42 constituents were identified in total. The number of identified constituents differed among populations. The lowest number of constituents were found in P1 (20 constituents); while the highest number was found in P7 (39).

Seven constituents were found at concentrations higher than $5.00 \%$ in at least one population: camphene, 1,8-cineole, $\alpha$-thujone, $\beta$-thujone, camphor, $\alpha$-humulene, and viridiflorol. These constituents were chosen for further analysis and were hereafter referred to as the main constituents. They constituted $72.40 \%$ (P6) to $78.39 \%$ (P4) of the essential oils of individual populations. Camphor was the dominant component in populations P2, P5 and P6, while it had an equal share with $\alpha$-thujone in population P3 (Table 2). On the other hand, in the populations $\mathrm{P} 1, \mathrm{P} 4$ and $\mathrm{P} 7, \alpha$-thujone was the most abundant compound (Table 2).

Table 3 shows the correlation between the seven main constituents of the essential oils of $S$. officinalis L. Strong negative correlations $(r<-0.70)$ have been observed between 1,8-cineole and $\alpha$-humulene.

Table 2

Composition (\%) and yields $(\%, v / v)$ of oils isolated from S. officinalis L. from seven populations from the North of Albania

\begin{tabular}{|c|c|c|c|c|c|c|c|c|c|c|}
\hline \multirow{2}{*}{ No. } & \multirow{2}{*}{ Constituents } & \multirow{2}{*}{$\mathbf{K I L}^{\mathbf{a})}$} & \multirow{2}{*}{$\mathbf{K I E}^{\mathbf{b})}$} & \multicolumn{7}{|c|}{ Content $[\%]^{\mathrm{c})}$} \\
\hline & & & & P1 & $\mathbf{P 2}$ & P3 & P4 & P5 & P6 & P7 \\
\hline 1 & Tricyclene & 921 & 924 & - & 0.40 & 0.45 & - & 0.45 & 0.12 & - \\
\hline 2 & $\alpha$-Pinene & 932 & 935 & 2.80 & 2.80 & 2.50 & 2.35 & 3.27 & 2.38 & 2.90 \\
\hline 3 & Camphene & 946 & 950 & 5.30 & 4.80 & 3.85 & 4.50 & 3.80 & 4.72 & 4.50 \\
\hline 4 & $\beta$-Pinene & 974 & 979 & 1.00 & 0.60 & 0.57 & 0.61 & 0.89 & 0.21 & 0.60 \\
\hline 5 & Myrcene & 991 & 993 & 1.50 & 1.00 & 0.94 & 1.00 & 0.86 & 0.71 & 1.00 \\
\hline 6 & $\alpha$-Phellandrene & 1005 & 1007 & - & 0.10 & tr. & tr. & tr. & tr. & $\operatorname{tr}$. \\
\hline 7 & $\alpha$-Terpinene & 1018 & 1019 & - & 0.20 & 0.19 & 0.19 & 0.17 & tr. & 0.10 \\
\hline 8 & $o$-Cymene & 1022 & 1029 & 0.60 & 0.50 & 0.50 & 0.53 & 0.33 & 0.82 & 0.50 \\
\hline 9 & Limonene & 1024 & 1031 & 1.80 & 1.50 & 1.44 & 1.85 & 1.15 & 1.82 & 1.60 \\
\hline 10 & 1,8-Cineole & 1026 & 1034 & 11.40 & 9.40 & 10.70 & 9.44 & 6.88 & 12.64 & 9.60 \\
\hline 11 & $\gamma$-Terpinene & 1054 & 1061 & 0.20 & 0.20 & 0.20 & 0.20 & 0.24 & tr. & 0.20 \\
\hline 12 & Terpinolene & 1086 & 1091 & - & 0.30 & 0.26 & 0.30 & 0.31 & 0.13 & 0.30 \\
\hline 13 & Linalool & 1095 & 1098 & - & 0.50 & 0.41 & 0.42 & 0.36 & 0.53 & 0.40 \\
\hline 14 & $\alpha$-Thujone & 1101 & 1111 & 22.80 & 22.00 & 24.08 & 24.29 & 19.87 & 20.10 & 21.60 \\
\hline 15 & $\beta$-Thujone & 1112 & 1120 & 6.40 & 4.70 & 5.92 & 5.98 & 9.14 & 5.52 & 4.00 \\
\hline 16 & 3-iso-Thujanol & 1134 & 1139 & - & - & - & tr. & 0.15 & - & - \\
\hline 17 & Camphor & 1141 & 1149 & 20.70 & 23.90 & 24.03 & 22.60 & 21.63 & 29.74 & 20.50 \\
\hline 18 & trans-Pinocamphone & 1159 & 1164 & - & - & tr. & - & tr. & tr. & tr. \\
\hline 19 & Borneol & 1165 & 1169 & 2.40 & 2.90 & 2.16 & 2.75 & 1.77 & 3.92 & 2.80 \\
\hline 20 & Terpinen-4-ol & 1174 & 1180 & 0.30 & 0.40 & 0.32 & 0.36 & 0.29 & 0.33 & 0.30 \\
\hline 21 & $\alpha$-Terpineol & 1186 & 1194 & - & 0.20 & 0.16 & 0.16 & 0.19 & 0.15 & 0.20 \\
\hline 22 & trans-Carveol & 1215 & 1220 & - & - & tr. & - & tr. & 0.10 & 0.10 \\
\hline 23 & Bornyl acetate & 1284 & 1289 & 1.90 & 2.70 & 1.86 & 2.36 & 2.11 & 2.27 & 2.50 \\
\hline 24 & Carvacrol & 1298 & 1301 & - & 0.30 & - & - & - & 0.12 & 0.10 \\
\hline 25 & $\alpha$-Copaene & 1374 & 1379 & - & $\operatorname{tr}$. & - & - & tr. & tr. & tr. \\
\hline 26 & trans-Caryophyllene & 1417 & 1423 & 1.80 & 3.40 & 3.21 & 2.22 & 3.02 & 0.59 & 3.20 \\
\hline 27 & Aromadendrene & 1439 & 1455 & - & - & - & - & 0.23 & $\operatorname{tr}$ & - \\
\hline 28 & $\alpha$-Humulene & 1453 & 1458 & 2.90 & 4.20 & 4.34 & 3.51 & 5.87 & 0.77 & 5.20 \\
\hline 29 & allo-Aromadendrene & 1458 & 1461 & - & 0.13 & 0.11 & 0.10 & 0.13 & tr. & 0.10 \\
\hline
\end{tabular}


T a b l e 2 (continue)

\begin{tabular}{|c|c|c|c|c|c|c|c|c|c|c|}
\hline \multirow{2}{*}{ No. } & \multirow{2}{*}{ Constituents } & \multirow{2}{*}{$\mathbf{K I L}^{\mathbf{a})}$} & \multirow{2}{*}{$\mathbf{K I E}^{\mathbf{b})}$} & \multicolumn{7}{|c|}{ Content [\% $]^{\mathrm{c})}$} \\
\hline & & & & P1 & P2 & P3 & P4 & P5 & P6 & P7 \\
\hline 30 & $\gamma$-Muurolene & 1478 & 1480 & - & tr. & tr. & tr. & tr. & tr. & tr. \\
\hline 31 & Viridiflorene & 1496 & 1499 & 0.30 & 0.20 & 0.25 & 0.22 & 0.25 & tr. & 0.20 \\
\hline 32 & $\gamma$-Cadinene & 1513 & 1517 & - & $\operatorname{tr}^{\mathrm{c})}$ & - & - & tr. & - & tr. \\
\hline 33 & $\delta$-Cadinene & 1522 & 1527 & - & tr. & tr. & tr. & tr. & - & tr. \\
\hline 34 & $\alpha$-Calacorene & 1544 & 1548 & - & tr. & - & - & - & - & tr. \\
\hline 35 & Spathulenol & 1577 & 1580 & - & - & - & - & tr. & - & tr. \\
\hline 36 & Caryophyllene oxide & 1582 & 1587 & 0.20 & 0.30 & 0.25 & 0.25 & 0.33 & 0.13 & 0.30 \\
\hline 37 & Viridiflorol & 1592 & 1596 & 4.50 & 5.90 & 5.33 & 5.67 & 5.84 & 4.91 & 7.00 \\
\hline 38 & Humulene epoxide II & 1606 & 1613 & - & 0.63 & 0.43 & 0.54 & 0.89 & 0.52 & 0.80 \\
\hline 39 & $\beta$-Eudesmol & 1649 & 1652 & - & $\operatorname{tr}$ & tr. & - & - & - & tr. \\
\hline 40 & Pimara-8,15-diene & 1948 & 1953 & - & - & - & - & 0.13 & - & 0.15 \\
\hline 41 & Manool & 2056 & 2060 & 1.70 & 2.30 & 2.06 & 2.08 & 4.67 & 1.55 & 4.10 \\
\hline \multirow[t]{2}{*}{42} & Labd-7,13-dien-15-ol & 2291 & 2300 & - & - & - & - & 0.23 & - & 0.20 \\
\hline & Total $(\%)$ & & & 90.50 & 96.46 & 96.52 & 94.48 & 95.45 & 94.79 & 95.05 \\
\hline \multirow{2}{*}{\multicolumn{4}{|c|}{ Chemical classes }} & \multicolumn{7}{|c|}{ Content $[\%]$} \\
\hline & & & & P1 & P2 & P3 & P4 & P5 & P6 & P7 \\
\hline \multicolumn{4}{|c|}{ Monoterpene hydrocarbons } & 13.20 & 12.40 & 11.00 & 11.63 & 11.57 & 11.21 & 11.80 \\
\hline \multicolumn{4}{|c|}{ Oxidized monoterpenes } & 65.90 & 67.00 & 69.84 & 68.46 & 62.59 & 75.51 & 62.20 \\
\hline \multicolumn{4}{|c|}{ Sesquiterpene hydrocarbons } & 5.00 & 8.43 & 8.11 & 6.25 & 9.90 & 1.86 & 9.20 \\
\hline \multicolumn{4}{|c|}{ Oxidized sesquiterpenes } & 4.70 & 6.93 & 6.11 & 6.46 & 7.16 & 5.56 & 8.30 \\
\hline \multicolumn{4}{|c|}{ Diterpenes } & I & I & I & I & 0.13 & I & 0.15 \\
\hline \multicolumn{4}{|c|}{ Oxidized diterpenes } & 1.70 & 2.30 & 2.06 & 2.08 & 4.90 & 1.55 & 4.30 \\
\hline \multicolumn{4}{|c|}{ Yield EO $(\%, \mathrm{v} / \mathrm{v})$} & 2.65 & 2.75 & 2.00 & 2.35 & 1.95 & 2.20 & 2.55 \\
\hline \multicolumn{4}{|c|}{$\begin{array}{l}\text { Content of EO (Ph.Eur.7.0.) (min. } 15 \mathrm{ml} / \mathrm{kg} \text { ) } \\
\text { Content of EO (ISO 6571/2008) (min. } 1.5 \%)\end{array}$} & 26.50 & 27.50 & 20.00 & 23.50 & 19.50 & 22.00 & 25.50 \\
\hline \multicolumn{4}{|c|}{$\begin{array}{l}\text { Satisfied the requirements of the ISO Std. } \\
9909 / 1997\end{array}$} & yes & no & yes & yes & no & no & yes \\
\hline
\end{tabular}

a) KIL - Kovats Index Literature [25]; ${ }^{\text {b) }}$ KIE - Kovats Index Estimated (AMDIS ver.2.1.); ${ }^{\text {c) }}$ tr. $=$ traces $(<0.10 \%)$.

Table 3

Pearson's correlation coefficients among the main essential oil constituents of Dalmatian sage populations from Albania

\begin{tabular}{lllllllll}
\hline \hline No. & Constituent & $\mathrm{C} 1$ & $\mathrm{C} 2$ & $\mathrm{C} 3$ & $\mathrm{C} 4$ & $\mathrm{C} 5$ & $\mathrm{C} 6$ & $\mathrm{C} 7$ \\
\hline $\mathrm{C} 1$ & Camphene & & $\mathrm{ns}$ & $\mathrm{ns}$ & $\mathrm{ns}$ & $\mathrm{ns}$ & $\mathrm{ns}$ & $\mathrm{ns}$ \\
$\mathrm{C} 2$ & 1,8 -Cineole & 0.559 & & $\mathrm{~ns}$ & $\mathrm{~ns}$ & $\mathrm{~ns}$ & $*$ & $\mathrm{~ns}$ \\
C3 & $\alpha$-Thujone & 0.065 & 0.160 & & $\mathrm{~ns}$ & $\mathrm{~ns}$ & $\mathrm{~ns}$ & $\mathrm{~ns}$ \\
C4 & $\beta$-Thujone & -0.448 & -0.503 & -0.281 & & $\mathrm{~ns}$ & $\mathrm{~ns}$ & $\mathrm{~ns}$ \\
C5 & Camphor & 0.021 & 0.583 & -0.292 & -0.149 & & $\mathrm{~ns}$ & $\mathrm{~ns}$ \\
C6 & $\alpha$-Humulene & -0.576 & -0.873 & 0.029 & 0.261 & -0.746 & & $\mathrm{~ns}$ \\
C7 & Viridiflorol & -0.365 & -0.578 & -0.121 & -0.321 & -0.393 & 0.683 & \\
\hline \hline
\end{tabular}

The significance of the correlations is indicated as follows: * - significance at the $5.00 \%$ nominal level; ns - not significant.

The Principal Component Analysis (PCA) of the seven main constituents in seven Dalmatian sage populations revealed that three principal compo- nents had an eigenvalue greater than 1 and explained $86.01 \%$ of the total variation (Table 4; Fig. 1A). 
Table 4

Component loadings of the seven essential oil constituents on the first three principal components

\begin{tabular}{llcccccc}
\hline \hline No. & Compound & PC1 & & PC2 & & PC3 & \\
\hline C1 & Camphene & 0.653 & $\mathrm{~ns}$ & 0.388 & $\mathrm{~ns}$ & 0.105 & $\mathrm{~ns}$ \\
$\mathrm{C} 2$ & 1,8 -Cineole & 0.944 & $* *$ & 0.137 & $\mathrm{~ns}$ & -0.021 & $\mathrm{~ns}$ \\
$\mathrm{C} 3$ & $\alpha$-Thujone & 0.068 & $\mathrm{~ns}$ & 0.622 & $\mathrm{~ns}$ & 0.607 & $\mathrm{~ns}$ \\
$\mathrm{C} 4$ & $\beta$-Thujone & -0.393 & $\mathrm{~ns}$ & -0.785 & $*$ & 0.460 & $\mathrm{~ns}$ \\
C5 & Camphor & 0.680 & $\mathrm{~ns}$ & -0.447 & $\mathrm{~ns}$ & -0.415 & $\mathrm{~ns}$ \\
C6 & $\alpha$-Humulene & -0.970 & $* * *$ & 0.153 & $\mathrm{~ns}$ & 0.028 & $\mathrm{~ns}$ \\
C7 & Viridiflorol & -0.680 & $\mathrm{~ns}$ & 0.413 & $\mathrm{~ns}$ & -0.590 & $\mathrm{~ns}$ \\
\hline & Eigenvalue & 3.341 & & 1.567 & & 1.112 & \\
& \% of variance & 47.73 & & 22.38 & & 15.89 & \\
\hline \hline
\end{tabular}

The significance is indicated as follows: $* * *$ - significance at the $0.10 \%$ nominal level;

** - significance at the $1.00 \%$ nominal level; * - significance at the $5.00 \%$ nominal level; ns - not significant.

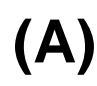

(A)

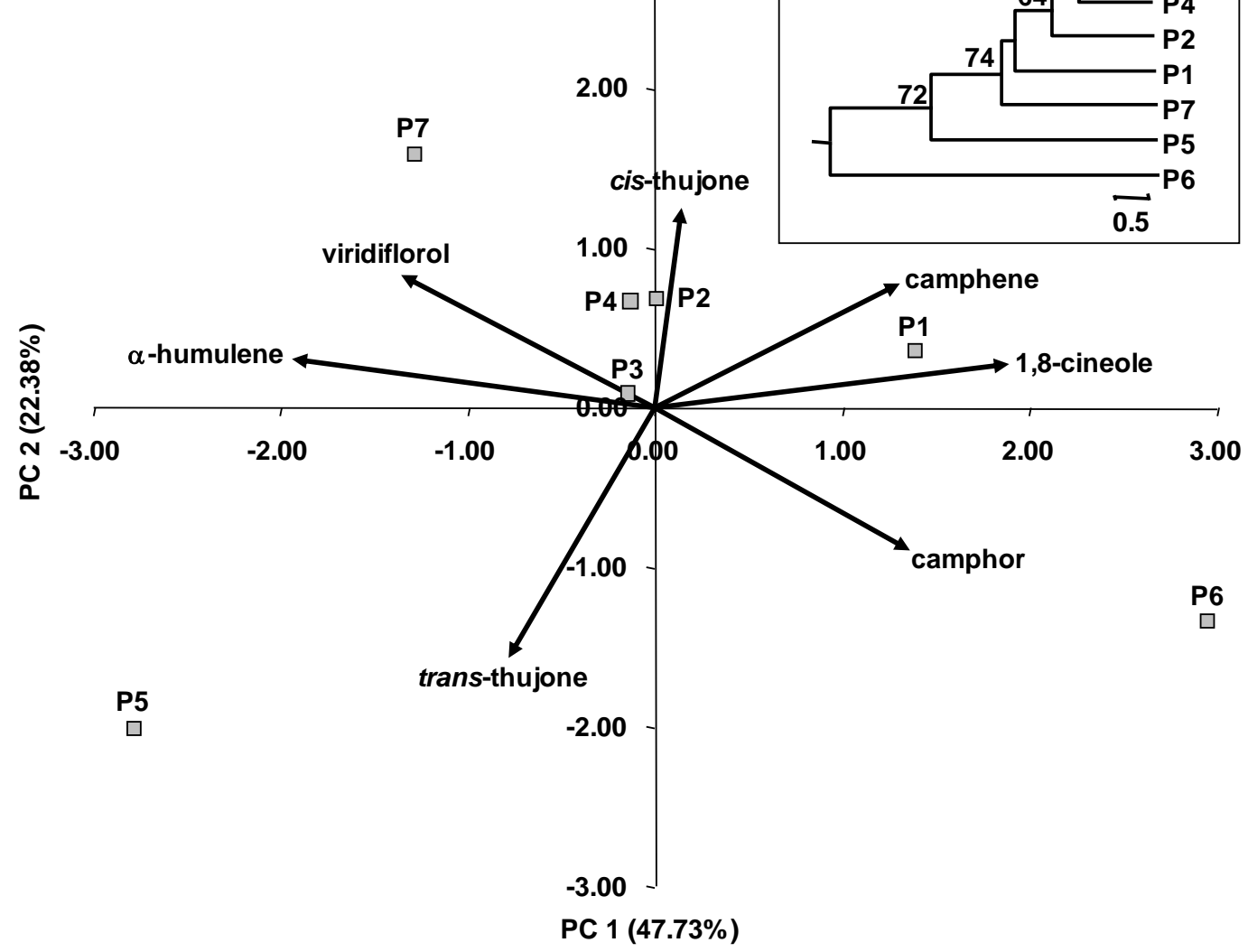

Fig. 1. Chemical diversity of Dalmatian sage populations from Albania: (A) Biplot of the PCA based on the seven main essential oil constituents (C1-C7); (B) UPGMA dendrogram based on the Euclidean distance matrix calculated for the contents of the seven main essential oil constituents.

The first PC explained $47.73 \%$ of the total variation and was strongly positively correlated with 1,8-cineole $(r>0.70 ; \mathrm{P}<0.05)$, while strongly negatively correlated with $\alpha$-humulene $(r<-0.70$; $\mathrm{P}<$ $0.05)$. Strong negative correlation was observed between the second $\mathrm{PC}$ and $\beta$-thujone $(r<-0.70$; $\mathrm{P}<$
0.05). The average Euclidean distance among populations based on seven main constituents was 6.12, ranging from 2.22 (between populations $\mathrm{P} 3$ and $\mathrm{P} 4$ ) to 11.83 (between P5 and P6). The highest net divergence defined as the sum of distances from a population to all the other populations was observed 
for population P6 (58.05) followed by P5 (45.27). As shown in the UPGMA dendrogram based on the Euclidean distance matrix, populations P5 and P6 were the most distant from the others (Figure 1B).

To characterize the natural variability between the S. officinalis L. populations, we compared the yield and chemical composition of the essential oils from seven locations in the North of Albania. The essential oil yield of the studied populations ranged from 1.95 to $2.75 \%$, and these data are very similar to the results reported for essential oil yield of sage populations from Croatia and Montenegro, ranging from 1.90 to $3.70 \%$ and 1.98 to $2.84 \%$, respectively. This shows that the oil yield varies depending on the origin of the plant material $[1,4,5]$. However, these results were higher compared to the results published by Cvetkovikj et al. [19] where the oil yield ranged from 0.15 to $1.70 \%$ for the six indigenous populations of $S$. officinalis L. from Albania.

In the analyzed populations, the main constituents were camphor (20.50-29.74\%) and $\alpha$-thujone (19.87-24.29\%), followed by 1,8-cineole (6.88$12.64 \%)$ and $\beta$-thujone (4.00-9.14\%). Populations $\mathrm{P} 1, \mathrm{P} 2, \mathrm{P} 3$, and $\mathrm{P} 4$ shared rather similar oil profiles. The oil of the population P5 had a higher amount of $\beta$-thujone $(9.14 \%)$ and $\alpha$-humulene $(5.87 \%)$ as compared to the rest of the populations. The oil of the population P6 was characterized by a higher amount of camphor (29.74\%) and 1,8-cineole $(12.64 \%)$ than the rest, while the population P7 showed a higher amount of viridiflorol $(7.00 \%)$ than the rest.

Camphor (13.00-41.00\%), followed by $\alpha$ thujone (4.00-26.00\%), 1,8-cineole $(2.00-16 \%)$ and $\beta$-thujone (1.00-11.00\%) were also identified as primary constituents of sage essential oils from different locations in Albania as reported by Schmiderer et al. [20].

According to Boszormenyi et al. [30], the chemical composition of the essential oils of $S$. officinalis L. that originated from different countries were divided into five groups according to the amount of the major constituents: 1 . camphor $>\alpha$ thujone $>1,8$-cineole $>\beta$-thujone; 2 . camphor $>\alpha$ thujone $>\beta$-thujone $>1,8$-cineole; 3 . $\beta$-thujone $>$ camphor $>1,8$-cineole $>\alpha$-thujone; 4 . 1,8-cineole $>$ camphor $>\alpha$-thujone $>\beta$-thujone and 5. $\alpha$-thujone $>$ camphor $>\beta$-thujone $>1,8$-cineole. Thus, populations $\mathrm{P} 2$ and $\mathrm{P} 6$ belong to group 1 together with population P3, which has almost equal shares of camphor and $\alpha$-thujone. The population P5 can be grouped within group 2 (camphor $>\alpha$-thujone $>\beta$ thujone $>1,8$-cineole). On the other hand, populations $\mathrm{P} 1, \mathrm{P} 4$ and $\mathrm{P} 7$ had a profile similar to that of the group 5 ( $\alpha$-thujone $>$ camphor $>\beta$-thujone $>1,8$ cineole), but the amount of 1,8-cineole was higher compared to $\beta$-thujone.

Except in populations from Albania [20], the essential oils, dominated by $\alpha$-thujone (16.98-40.35 $\%)$, camphor (12.75-35.37\%), 1,8-cineole (6.40$12.06 \%)$ and $\beta$-thujone (1.50-10.35\%), were recorded in indigenous population of $S$. officinalis $\mathrm{L}$. from Montenegro [5].

Unlike our results, those that originated from Croatia were dominated by $\beta$-thujone $(10.30-49.30$ $\%$ ), camphor (5.20-36.50\%), $\alpha$-thujone (1.50$44.90 \%)$ and 1,8-cineole (5.00-15.70\%) [4]. On the other hand, the essential oil content from populations that originated from the North of Tunisia were dominated by 1,8 -cineole $(33.27 \%), \beta$-thujone (18.40\%), $\alpha$-thujone (13.45\%), and borneol (7.39 $\%)$ [31], while the main chemical constituents of populations that originated from Serbia were dominated by camphor (1.90-32.70\%), $\alpha$-thujone (6.70$28.50 \%), \alpha$-humulene (3.40-33.30\%), viridiflorol $(2.9-12.40 \%)$ and manool (1.40-14.50\%) [32].

The chemical composition of the essential oils of sage varies depending on several factors, such as genetic background [33-35], environmental conditions [34-38], season [34], plant parts used for the extraction of essential oil [34, 38, 39], soil mineral fertilization [40], etc.

The relative amounts of camphor and $\alpha$ - and $\beta$-thujone determine the quality of essential oils of Dalmatian sage. The best quality of Dalmatian sage essential oil is in the cases where $\alpha$ - and $\beta$-thujone (together) are present at up to $50.00 \%$ of the total percentage of essential oil, while the relative amount of camphor is not lower than $20.00 \%$ [34, 41-43]. International standards require 18.00-43.00 $\%$ of $\alpha$-thujone and $3.00-8.50 \%$ of $\beta$-thujone [23]. Thus, the essential oils of the populations P1, P3, $\mathrm{P} 4$, and $\mathrm{P} 7$ comply with the requirements of the ISO 9909/1997 standard for Dalmatian sage essential oil composition.

\section{CONCLUSION}

Variability between the chemical composition and content of the essential oil from the seven different Dalmatian sage populations of North Albania was recorded.

The yield of sage essential oils ranged from 1.95 to $2.75 \%$. All populations had possessed oil content within the requirements of the European Pharmacopeia 7.0. [21] and ISO 6571/2008 Standard [22].

P1, P2, P3 and P4 populations showed a similar chemical oil profile. On the other hand, it was 
confirmed by statistical analysis that populations P5 and P6 differed the most in the chemical composition of their oils. Finally, populations: P1, P3, P4 and P7 comply with the requirements of the ISO 9909/1997 Standard for the Dalmatian sage essential oil composition [23].

Author contribution statement: A. I., A. D. and V. P. designed the study; Gj. S. and I. C. K. performed chemical analyses, Z. S. and A. I. performed data analyses, A. I. and A. H. wrote the manuscript, N. G. and Z. S. scientifically improved and corrected the manuscript.

\section{REFERENCES}

[1] S. E. Kintzios (Ed.), Sage: The Genus Salvia. Harwood Academic Publishers, Amsterdam, 2008.

[2] A. Tucker, M. J. Maciarello, J. T. Howell, Botanical aspects commercial sage. Econ. Bot., 34, 16-19 (1980).

[3] J. C. Chalchat, A. Michet, B. Pasquier, Study of clones of Salvia officinalis L. yields and chemical composition of essential oil. Flavour Fragr. J., 13, 68-70 (1998). DOI: $10.1002 /($ SICI)1099-1026(199801/02)13:1<68::AIDFFJ698>3.0.CO;2-8

[4] M. Jug-Dujakovic, M. Ristic, D. Pljevljakusic, Z. DajicStevanovic, Z. Liber, K. Hancevic, T. Radic, Z. Satovic, High diversity of indigenous populations of Dalmatian sage (Salvia officinalis L.) in essential-oil composition. Chem. Biodivers., 9, 2309-2323 (2012).

DOI: $10.1002 / \mathrm{cbdv} .201200131$

[5] D. Stešević, M. Ristic, V. Nikolic, M. Nedovic, D. Cakovic, Z. Satovic, Chemotype diversity of indigenous Dalmatian sage (Salvia officinalis L.) populations in Montenegro, Chem. Biodivers., 11, 101-113 (2014). DOI: $10.1002 / \mathrm{cbdv} .201300233$

[6] W. Greuter, H. M. Burdet, G. Long, Med-Checklist, A critical inventory of vascular plants of the circum-Mediterranean countries. Vol. 3 (Dicotyledones: Convolvulaceae-Labiatae). OPTIMA Secretariat, Med-Checklist Trust of OPTIMA, Euro+Med Plantbase Secretariat, 1986.

[7] L. Hornok, Influence of nutrition on the yield and content of active compounds in some essential oil plants. Acta Hortic., 132, 239-247 (1983).

DOI: $10.17660 /$ ActaHortic.1983.132.26

[8] Y. Lu, L. Foo, Flavonoid and phenolic glycosides from Salvia officinalis. Phytochem., 55, 263-267 (2000). DOI: $10.1016 / \mathrm{s} 0031-9422(00) 00309-5$

[9] U. Asllani, The essential oils of Medicinal and Aromatic Plants from Albania, published by ILAR, Tirana, Albania, 2004.

[10] A. Ibraliu, S. Baldev Dhillon, N. Faslia, B. Stich, Variability of essential oil composition in Albanian accessions of Satureja montana L. J. Med. Plant. Res., 4, 1359-1364 (2010). DOI: 10.5897/JMPR10.007

[11] S. Karaj, N. Gruda, A. Ibraliu, J. Müller, Medicinal and Spice Plants in Albania. J. Med. Spice Plants (Zeitschrift fur Arznei-\& Gewurzpflanzen), 22, 66-68 (2017). (in German)
[12] A. Pieroni, B. Dibra, G. Grishaj, I. Grishaj, S. Gjon Mazai, Traditional phytotherapy of the Albanians of Lepushe, Northern Albanian Alps. Fitoterapia, 76, 379399 (2005). DOI: 10. 1016/j.fitote.2005.03.015

[13] J. Vangjeli, F. Mullaj, Red Book of Albanian Flora, Tiranë, Albania, 2012.

[14] D. Baricevic, S. Sosa, R. Della Loggia, A. Tubaro, B. Simonovska, A. Krasna, A. Zupancic, Topical anti-inflammatory activity of Salvia officinalis L. Leaves: the relevance of ursolic acid. J. Ethnopharmacol., 75, 125-132 (2001). DOI: 10.1016/S0378-8741(00)00396-2

[15] V. Jalsenjak, S. Peljnajk, D. Kustrak, Microcapsules of sage oil, essential oils content and antimicrobial activity. Pharmazie, 42, 419-420 (1987).

[16] B. Tepe, M. Sokmen, H. A. Akpulat, A. Sokmen, Screening of the antioxidant potentials of six Salvia species from Turkey, Food Chem., 95, 200-204 (2006). DOI: $10.1016 /$ j.foodchem.2004.12.031

[17] I. Cvetkovikj, G. Stefkov, J. Acevska, J. Petreska, M. Karapandzova, M. Stefova, A. Dimitrovska, S. Kulevanova, Polyphenolic characterization and chromatographic methods for fast assessment of culinary Salvia species from South East Europe, J. Chromatogr. A, 1282, 38-45 (2013).

DOI: $10.1016 /$ j.chroma.2012.12.068

[18] I. Cvetkovikj, G. Stefkov, M. Karapandzova, S. Kulevanova, Z. Šatović. Essential oils and chemical diversity of Southeast European populations of Salvia, Chem. Biodivers., 12, 1025-1039 (2015). DOI: $10.1002 / \mathrm{cbdv} .201400273$

[19] I. Cvetkovikj, G. Stefkov, J. Acevska, J. H. Cho, M. A. Krapandzova, Dimitrovska, S. Kulevanova, Headspace screening: A novel approach for fast quality assessment of the essential oil from culinary sage. Food Chem., 202, 133-140 (2016). DOI: 10.1016/j.foodchem.2016.01.141

[20] C. Schmiderer, P. Torres-Londoco, J. Novak, Proof of geographical origin of Albanian sage by essential oil analysis. Biochem. Sys. Ecol., 51, 70-77 (2013). DOI: $10.1016 /$ j.bse.2013.08.007

[21] European Pharmacopoeia, 7th Ed. Council of Europe, Strasbourg, France, 2011.

[22] International Organization for Standardisation (ISO), ISO 6571, Spices, condiments and herbs - Determination of volatile oil content (hydrodistillation method), 2008.

[23] International Organization for Standardisation (ISO), ISO 9909, Oil of Dalmatian Sage (Salvia officinalis L.), 1997.

[24] Xh. Qosja, K. Paparisto, M. Demiri, J. Vangjeli, E. Balza, Flore de l'Albanie. (Florae Shqiperise). Vol. 2. Akademia e Shkencave e Republikes se Shqiperise Qendra e Kërkimeve Biologjike, Tiranë, 1992.

[25] R. P. Adams, Identification of Essential Oil Components by Gas Chromatography/Mass Spectrometry, Allured Publishing Corporation, IL, USA, 2007.

[26] Automated Mass Spectral Deconvolution and Identification System software (AMDIS ver.2.1.), National Institute of Standards and Technology (NIST), Standard Reference Data Program, Gaithersburg, MD (USA).

[27] SAS Institute, SAS/STAT ${ }^{\circledR} 9.1$ User's Guide. SAS Institute Inc., Cary, NC, 2004 
[28] J. Felsenstein, Confidence limits on phylogenies: an approach using the bootstrap. Evolution, 39, 783-791 (1985). DOI: $10.2307 / 2408678$

[29] Ø. Hammer, D. A. T. Harper, P. D. Ryan, PAST: Paleontological statistics software package for education and data analysis. Palaeontol. Electron., 4, 9 (2001).

[30] A. Böszörményi, E. Héthelyi, A. Farkas, G. Horváth, N. Papp, E. Lemberkovics, E. Szoke, Chemical and genetic relationships among sage (Salvia officinalis L.) cultivars and Judean sage (Salvia judaica Boiss.). J. Agric. Food Chem., 10; 57(11) (2009). DOI: 10.1021/jf9005092

[31] A. Hayouni, I. Chraief, M. Abedrabba, M. Bouix, J. Y. Leveau, H. Mohammed, M. Hamdi, Tunisian Salvia officinalis L. and Schinus molle L. essential oils: their chemical compositions and their preservative effects against Salmonella inoculated in minced beef meat. Int J. Food Microbiol., 125, 242-251 (2008).

DOI: $10.1016 / j$. .jffoodmicro.2008.04.005

[32] B. Lakušić, M. Ristić, V. Slavkovska, D. Stojanović, D. Lakušić, Variations in essential oil yields and compositions of Salvia officinalis (Lamiaceae) at different developmental stages. Bot. Serb., 37, 127-139 (2013).

[33] E. Mader, U. Lohwasser, A. Brner, J. Novak, Population structures of gene bank accessions of Salvia officinalis L. (Lamiaceae) revealed by high resolution melting analysis. Biochem. Sys. Ecol., 38, 178-186 (2010). DOI: 10.1016/j.bse.2010.01.001

[34] N. B. Perry, R. E. Anderson, N. J. Brennan, M. H. Douglas, A. J. Heaney, J. A. McGimpsey, B. M. Smallfield, Essential Oils from Dalmatian Sage (Salvia officinalis L.): Variations among Individuals, Plant Parts, Seasons, and Sites. J. Agric. Food Chem., 47, 2048-2054 (1999). DOI: $10.1021 / \mathrm{jf} 981170 \mathrm{~m}$

[35] D. Grulova, I. Salamon, Essential oil composition of garden sage tea from different origin, Biologični Sistemi, 5 (4), 412-415 (2013)
[36] I. Bettaieb, N. Zakhama, W. Aidi Wannes, M. E. Kchouk, B. Marzouk, Water deficit effects on Salvia officinalis fatty acids and essential oils composition. Sci. Hortic., 120, 271-275 (2009).

DOI: 10.1016/j.scienta.2008.10.016

[37] Y. L. Li, L. E. Craker, T. Potter, Effect of light level on essential oil production of sage (Salvia officinalis) and thyme (Thymus vulgaris). In: Proceedings Int. Symp. Medicinal and Aromatic Plants. Acta Hortic., 426, 419-426 (1996). DOI: 10.17660/ActaHortic.1996.426.46

[38] P. C. Santos-Gomes, M. Fernandes-Ferreira, Organ and season dependent variation in the essential oil composition of Salvia officinalis L. cultivated in two different sites. J. Agric. Food Chem., 49, 2908-2916 (2001). DOI: $10.1021 / \mathrm{jf001102b}$

[39] A. Hadri, M. Gomez Del Rio, J. Sanz, A. Coloma, M. Idaomar, B. Ozanas, Cytotoxic activity of $\alpha$-humulene and trans-caryophyllene from Salvia officinalis in animal and human tumor cells. An. R. Acad. Nac. Farm., 76, 343-356 (2010).

[40] R. Piccaglia, M. Marotti, Characterisation of several aromatic plants grown in northern Italy. Flavour Frag. J., 8, 115-122 (1993). DOI: 10.1002/ffj.2730080208

[41] J. Poracová, B. Taylorová, I. Salamon, Essential Oil from Salvia officinalis L. and Its Effect on Microbial Parameters of Piglets in a Model Experiment. Herba Polonica, 55 (4), 78-85.

[42] E. Guenther, Oil of sage. In: The Essential Oils; Krieger: FL. Malabar, 1949, pp. 710-717.

[43] E. Putievsky, U. Ravid, D. Sanderovich, Morphological observations and essential oils of sage (Salvia officinalis L.) under cultivation. J. Essent. Oil Res., 4, 291-293 (1992). DOI: https://doi.org/10.1080/10412905.1992.9698064 
